\title{
BILANGAN DOMINASI EKSENTRIK TERHUBUNG PADA GRAF SUNLET DAN GRAF BISHOP
}

\author{
Bambang Poniman, Yundari, Fransiskus Fran
}

\section{INTISARI}

\begin{abstract}
Diberikan $V$ suatu himpunan titik pada suatu graf $G$. Sebuah himpunan $D \subseteq V$, dikatakan himpunan dominasi pada graf $G=(V, E)$ jika semua titik yang tidak berada pada himpunan $D$ bertetangga sedikitnya dengan satu titik dari D. Kardinalitas minimum dari D disebut bilangan dominasi $(\gamma(G))$. Suatu himpunan $D \subseteq V(G)$ disebut himpunan dominasi eksentrik terhubung jika $D$ adalah himpunan dominasi eksentrik dari $G$ dan subgraf induksi dari himpunan dominasi eksentrik yang dibangun oleh $D$ $(<D>)$ terhubung. Kardinalitas minimum dari setiap himpunan dominasi eksentrik terhubung disebut bilangan dominasi eksentrik terhubung dari $G$ dan dinotasikan sebagai $\gamma_{c e}(G)$. Pada penelitian ini dikaji tentang bilangan dominasi eksentrik terhubung pada graf sunlet $S_{n}$ dan graf bishop $B_{m, n}$. Pada graf sunlet $S_{n}$ dengan $n$ adalah banyaknya anting yang ditambahkan pada graf cycle. Pada graf bishop $B_{m, n}$ dengan $m$ dan $n$ menjelaskan banyaknya baris dan kolom pada kotak papan catur. Hasil penelitian yang diperoleh bahwa $\gamma_{c e}\left(S_{n}\right)=n+\frac{n}{2}$, untuk $n$ genap, dan $\gamma_{c e}\left(S_{n}\right)=n+\left\lceil\frac{n}{3}\right\rceil$, untuk $n$ ganjil. Pada graf bishop $B_{m, n}$ dibatasi dengan $m=2, m=3$ dan $n$ genap. Lebih lanjut untuk $B_{3, n}$ dengan $2 \leq n \leq 18$ adalah $\gamma_{c e}\left(B_{2, n}\right)=n-1, \quad \gamma_{c e}\left(B_{3,2}\right)=2, \quad \gamma_{c e}\left(B_{3, n}\right)=n-1,4 \leq n \leq 8, \quad \gamma_{c e}\left(B_{3, n}\right)=n-2,10 \leq$ $n \leq 18$.
\end{abstract}

Kata Kunci : eksentrisitas, titik eksentrik, subgraf induksi.

\section{PENDAHULUAN}

Matematika merupakan cabang ilmu yang banyak digunakan dalam kehidupan sehari-hari, salah satu teori dalam matematika yang banyak manfaatnya adalah teori graf. Secara garis besar teori graf adalah metode untuk mencari pasangan himpunan antara himpunan titik dan himpunan sisi. Diberikan suatu graf $G=(V, E)$, dimana $V$ himpunan titik dan $E$ himpunan sisi. Misalkan $D$ merupakan himpunan bagian dari $V$, jika setiap titik dari $V-D$ saling bertetangga setidaknya dengan satu titik dari $D$, maka $D$ dikatakan himpunan dominasi pada graf $G$. Bilangan dominasi pada graf $G$ dinotasikan dengan $\gamma(\mathrm{G})$ yaitu kardinalitas minimum dari semua himpunan dominasi dari graf $G$ [1].

Selain himpunan dominasi, salah satu pembahasan yang terus berkembang pada teori graf adalah eksentrisitas dari suatu graf. Secara umum, eksentrisitas pada suatu graf $G=(V, E)$ diartikan sebagai jarak maksimum dari $u, v \in V$ pada graf $G$. Titik $v$ disebut titik eksentrik jika jarak dari $v$ ke $u$ sama dengan $e(u)$ [2]. Jika konsep himpunan dominasi dan konsep eksentrisitas dipadukan maka diperoleh konsep baru yaitu konsep bilangan dominasi eksentrik. Suatu himpunan $D \subseteq V(G)$ disebut himpunan dominasi eksentrik, jika $D$ adalah himpunan dominasi dari $G$ dan untuk setiap titik $v$ di $V-D$ terdapat setidaknya satu titik eksentrik dari $v$ di $D$. Kardinalitas minimum dari setiap himpunan dominasi eksentrik disebut bilangan dominasi eksentrik dari $G$ dan dinotasikan sebagai $\gamma_{e d}(G)$. Lebih lanjut, jika $D$ adalah himpunan dominasi eksentrik dari $\mathrm{G}$ dan subgraf induksi dari himpunan dominasi eksentrik yang dibangun oleh $D(\langle D\rangle)$ terhubung, maka $D$ merupakan himpunan dominasi eksentrik terhubung. Kardinalitas dari setiap himpunan dominasi eksentrik terhubung minimum disebut bilangan dominasi eksentrik terhubung dari $G$ dan dinotasikan sebagai $\gamma_{c e}(G)$.

Pada penelitian ini penulis menerapkan himpunan dominasi ke dalam permainan catur khususnya pada pergerakan bishop, dimana dari setiap satu gerakan bishop yang memungkinkan tidak bertabrakan dengan bishop lainya. Dalam pola pergerakan bidak catur, bishop dapat bergerak 
sepanjang petak secara diagonal, tetapi tidak dapat melompati bidak lain, dari pergerakan bishop akan terbentuk graf bishop, dengan demikian peneliti menganalisis bilangan dominasi eksentrik terhubung pada graf bishop. Selain itu berdasarkan penelitian [3], penelitian ini juga mengembangkan penelitian tersebut, dengan menganalisis bilangan dominasi eksentrik terhubung pada graf sunlet. Graf sunlet adalah sebuah graf dengan $2 n$ titik yang diperoleh dengan menambahkan $n$ anting pada $C_{n}$.

Pengembangan materi dalam kasus mencari bilangan dominasi eksentrik terhubung merupakan topik yang menarik untuk dibahas lebih lanjut. Pada penelitian ini akan mencari formula bilangan dominasi eksentrik terhubung pada beberapa graf. Graf yang menjadi fokus utama pada penelitian ini adalah graf sunlet dan graf bishop.

\section{GRAF SUNLET DAN GRAF BISHOP}

Graf $G$ didefinisikan sebagai pasangan himpunan $(V, E)$, ditulis dengan notasi $G=(V, E)$, yang dalam hal ini $V$ adalah himpunan tidak-kosong dari titik-titik (vertices) dan $E$ adalah himpunan sisi (edges) yang menghubungkan sepasang titik. Sebuah graf dimungkinkan tidak mempunyai sisi satu buah pun, tetapi titiknya harus ada, minimal satu [4]. Dalam penelitian ini titik pada graf dinyatakan dengan $u_{i}$ atau $v_{i}$ untuk $i \in \mathbb{N}$. Beberapa terminologi dasar yang berkaitan dengan teori graf yang digunakan dalam penelitian ini yaitu bertetangga, lintasan, terhubung dan lingkaran [3], dua buah simpul pada graf tak-berarah $G$ dikatakan bertetangga bila keduanya terhubung langsung dengan sebuah sisi. Dengan kata lain, $u$ bertetangga dengan $v$ jika $(u, v)$ adalah sebuah sisi pada graf $G$. Lintasan yang panjangnya $n$ dari simpul awal $v_{1}$ ke simpul tujuan $v_{n}$ di dalam graf $G$ ialah barisan berselang-seling simpul-simpul dan sisi-sisi yang berbentuk $v_{1}, e_{1}, v_{2}, e_{2}, \ldots, v_{n-1}, e_{n}, v_{n}$ sedemikian sehingga $e_{1}=\left(v_{1}, v_{2}\right), e_{2}=\left(v_{2}, v_{3}\right), \ldots, e_{n}=\left(v_{n-1}, v_{n}\right)$ adalah sisi-sisi dari graf $G$. Lintasan yang berawal dan berakhir pada titik tujuan disebut terhubung. Graf dapat dikelompokkan menjadi beberapa jenis, dalam penelitian ini jenis graf yang digunakan adalah graf sunlet dan graf bishop.

Graf sunlet adalah sebuah graf dengan $2 n$ titik yang diperoleh dengan menambahkan $n$ anting pada $C_{n}$ dan dinotasikan $S_{n}$ [5]. Graf bishop adalah sebuah graf yang berukuran $m \times n$ yang dinotasikan dengan $\left(B_{m, n}\right)$ memiliki himpunan titik $V\left(B_{m, n}\right)=\{(x, y) \mid 0 \leq x \leq n-1,0 \leq y \leq m-1\}$ dengan himpunan sisi $E\left(B_{m, n}\right)$ berisi semua sisi dari $(x, y)$ ke $(w, z)$ dimana titik $(x, y)$ dapat bergerak ke titik $(w, z)[6]$. Adapun contoh dari graf sunlet pada Gambar 1 (a) dengan 6 titik dan 6 sisi, contoh graf bishop pada Gambar 1(b) dengan 3 titik dan 4 sisi serta Gambar 1(c) dengan 6 titik dan 8 sisi. Bentuk graf sunlet dan graf bishop dapat dilihat pada Gambar 1.

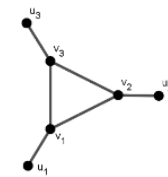

(a)

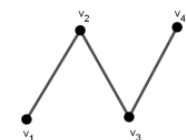

(b)

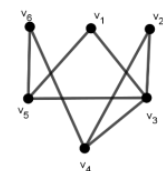

(c)

Gambar 1 (a) graf sunlet $S_{3}$, (b) graf bishop $B_{2,4}$, (c) graf bishop $B_{3,4}$

\section{BILANGAN DOMINASI EKSENTRIK TERHUBUNG}

Salah satu topik yang dibahas dalam teori graf ialah himpunan dominasi. Banyak manfaat himpunan dominasi dalam kehidupan sehari-hari seperti yang disebutkan oleh Haynes dkk (1998) diantaranya dalam rute bus sekolah. Adapun definisi himpunan dominasi sebagai berikut:

Definisi 1 [1] Diketahui graf $G=(V, E)$. Misalkan D merupakan subset dari $V$. Jika setiap titik dari $V-D$ saling bertetangga setidaknya dengan satu titik dari $D$, maka $D$ dikatakan himpunan dominasi pada graf $G$. Bilangan dominasi pada graf $G$ dinotasikan dengan $\gamma(G)$ merupakan kardinalitas minimum dari semua himpunan dominasi.

Contoh 2 Misal diberikan graf $G$ seperti pada Gambar 2, dengan 4 titik dan 3 sisi. Selanjutnya, ditentukan bilangan dominasi pada graf $G$ tersebut. 


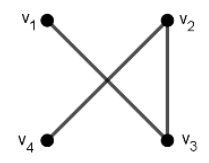

\section{Gambar 2 Bilangan Dominasi pada Graf $G$}

Pada Gambar 2 dapat dipilih beberapa kemungkinan himpunan dominasi pada graf $G$ yaitu $\left\{v_{1}, u_{2}\right\},\left\{v_{2}, v_{3}\right\},\left\{v_{1}, v_{2}, v_{3}\right\}$ dan $\left\{v_{2}, v_{3}, v_{4}\right\}$. Berdasarkan beberapa kemungkinan, didapat bilangan dominasi pada graf $G$ yaitu $\gamma(G)=2$.

Bilangan dominasi eksentrik terhubung merupakan salah satu pengembangan dari bilangan dominasi. Definisi dari himpunan dominasi eksentrik sebagai beriku.

Definisi 3 [7] Suatu himpunan $D \subseteq V(G)$ disebut himpunan dominasi eksentrik jika $D$ adalah himpunan dominasi dari graf $G$ dan untuk setiap titik $v$ di $V-D$ terdapat setidaknya satu titik eksentrik dari $v$ di D. Kardinalitas minimun dari setiap himpunan dominasi eksentrik disebut bilangan dominasi eksentrik dari $G$ dan dinotasikan sebagai $\gamma_{e d}(G)$.

Adapun definisi dari bilangan dominasi eksentrik terhubung dijelaskan pada definisi berikut.

Definisi 4 [7] Suatu himpunan $D \subseteq V(G)$ disebut himpunan dominasi eksentrik terhubung jika $D$ adalah himpunan dominasi eksentrik dari $G$ dan subgraf induksi dari himpunan dominasi eksentrik yang dibangun oleh $D(<D>)$ terhubung. Kardinalitas dari setiap himpunan dominasi eksentrik terhubung minimum disebut bilangan dominasi eksentrik terhubung dari $G$ dan dinotasikan sebagai $\gamma_{c e}(G)$.

Contoh 5 Misal diberikan graf $G$ seperti pada Gambar 2, dengan 4 titik dan 3 sisi. Selanjutnya, ditentukan bilangan dominasi eksentrik terhubung pada graf $G$ tersebut. Pada Gambar 2 diperoleh titik eksentrik seperti pada Tabel 1.

Tabel 1 Eksentrisitas dari graf $G$

\begin{tabular}{|c|c|c|}
\hline Titik & Eksentrisitas & Titik eksentrik \\
\hline$v_{1}$ & 3 & $v_{4}$ \\
\hline$v_{2}$ & 2 & $v_{1}$ \\
\hline$v_{3}$ & 2 & $v_{4}$ \\
\hline$v_{4}$ & 3 & $v_{1}$ \\
\hline
\end{tabular}

Pada Tabel 1 diperoleh eksentrisitas dan titik eksentrik pada graf $G$. Kemudian ditentukan himpunan dominasi eksentrik pada graf $G$ yang diperoleh dari titik $v$ di $V-D$ yang mempunyai setidaknya satu titik eksentrik dari $v$ di $D$. Diketahui bahwa $V=\left\{v_{1}, v_{2}, v_{3}, v_{4}\right\}$, untuk $D^{\prime}=$ $\left\{v_{1}, v_{2}, v_{3}\right\}$ maka untuk $V-D^{\prime}=\left\{v_{4}\right\}$, karena $D^{\prime}$ merupakan himpunan dominasi eksentrik terhubung dan $\langle D\rangle$ juga merupakan subgraf induksi terhubung dari graf $G$ maka di peroleh bilangan dominasi eksentrik terhubung $\gamma_{c e}(G)=3$. Sedangkan untuk $D_{1}=\left\{v_{1}, v_{4}\right\}$ merupakan himpunan dominasi eksentrik tetapi bukan merupakan himpunan dominasi eksentrik terhubung.

\section{Bilangan Dominasi Eksentrik Terhubung pada Graf $S_{n}$}

Pada graf sunlet dapat dicari bilangan dominasi eksentrik terhubungnya. Berikut ini diberikan proposisi untuk mencari bilangan dominasi eksentrik terhubung pada graf sunlet $S_{n}$ :

Proposisi 6 Jika diberikan graf $S_{n}$ untuk $n \geq 3$ maka

$$
\gamma_{\text {ce }}\left(S_{n}\right)=\left\{\begin{array}{l}
n+\frac{n}{2}, \text { jika } n \geq 4, \text { untuk } n \text { genap } \\
n+\left[\frac{n}{3}\right], \text { jika } n \geq 3, \text { untuk } n \text { ganjil }
\end{array} .\right.
$$


Bukti: Diberikan graf sunlet dengan $2 n$ titik, $n \geq 3$. Graf sunlet memiliki jumlah titik dan sisi yang sama yaitu sebanyak $2 n$, titik pada graf sunlet berderajat 3 kecuali $\left\{u_{1}, u_{2}, \ldots, u_{n}\right\}$ dengan derajat titik adalah 1.

Kasus I : jika $n \geq 4$, untuk $n$ genap

Misalkan ambil sebarang $v_{i} \in V\left(S_{n}\right)$, dengan $i=1,2,3, \ldots, n$. Akibatnya $v_{i}$ akan mendominasi titik pada $\left\{v_{i+1}, v_{i-1}, u_{i}\right\}$, dengan $v_{n+1}=v_{1}$ dan $v_{0}=v_{n}$. Jadi setiap titik bisa mendominasi maksimal 3 titik (4 termasuk diri nya sendiri). Oleh karena itu dapat dipilih salah satu himpunan dominasi pada graf sunlet $\left(S_{n}\right)$ yaitu $S_{1}=\left\{v_{1}, v_{2}, \ldots, v_{n}, u_{1}, u_{2}, \ldots, u_{\frac{n}{2}}\right\}$. Dari sini $S_{1}$ himpunan dominasi eksentrik karena terdapat minimal satu titik eksentrik dari $v_{i}$ di $S_{1}$. Lebih lanjut $S_{1}$ himpunan dominasi eksentrik terhubung karena $<S_{1}>$ merupakan subgraf induksi terhubung dari graf sunlet. Akibatnya diperoleh bilangan dominasi eksentrik terhubung $\gamma_{c e}\left(S_{n}\right) \leq n+\frac{n}{2}$. Selanjutnya, akan ditunjukkan bilangan dominasi eksentrik terhubung pada graf sunlet $\gamma_{c e}\left(S_{n}\right)=n+\frac{n}{2}$. Andaikan $\gamma_{c e}\left(S_{n}\right)=n+\frac{n}{2}-1$ maka terdapat $n+\frac{n}{2}-1$ titik sehingga kardinalitas minimum himpunan dominasi eksentrik terhubung pada graf sunlet. Jika terdapat $n+\frac{n}{2}-1$ titik pada himpunan dominasi eksentrik terhubung yang dipilih sebarang maka mengakibatkan minimal 1 titik pada graf sunlet tidak terhubung atau tidak mempunyai titik eksentrik dari $v_{i}$ di $D$ pada graf sunlet. Jadi, dapat disimpulkan bilangan dominasi eksentrik terhubung pada graf sunlet yaitu $\gamma_{c e}\left(S_{n}\right)=n+\frac{n}{2} \mathbf{m}$.

Kasus II : jika $n \geq 3$, untuk $n$ ganjil

Misalkan ambil sebarang $v_{i} \in V\left(S_{n}\right)$, dengan $i=1,2,3, \ldots, n$. Sehingga $v_{i}$ akan mendominasi titik pada $\left\{v_{i+1}, v_{i-1}, u_{i}\right\}$, dengan $v_{n+1}=v_{1}$ dan $v_{0}=v_{n}$. Jadi setiap titik bisa mendominasi maksimal 3 titik (4 termasuk dirinya sendiri). Oleh karena itu dapat dipilih salah satu himpunan dominasi eksentrik terhubung pada graf sunlet $\left(S_{n}\right)$ yaitu

$S=\left\{v_{1}, v_{2}, \ldots, v_{n}, u_{1}, u_{4}, u_{7}, \ldots, u_{n-5}, u_{n-2}\right\}$ untuk $n=6 k-3, k \in \mathbb{N}$,

$S=\left\{v_{1}, v_{2}, \ldots, v_{n}\right\} \cup\left\{u_{1}, u_{5}, u_{11}, u_{15}, \ldots, u_{n-2}\right\} \cup\left\{u_{4}, u_{8}, u_{14}, \ldots, u_{n-5}\right\}$ untuk $n=6 k-1, k \in \mathbb{N}$, $S=\left\{v_{1}, v_{2}, \ldots, v_{n}\right\} \cup\left\{u_{1}\right\} \cup\left\{u_{2}, u_{5}, u_{7}, u_{10}, u_{13}, \ldots, u_{n-4}, u_{n-1}\right\}$ untuk $n=6 k+1, k \in \mathbb{N}$.

Dari sini $S$ himpunan dominasi eksentrik karena terdapat minimal satu titik eksentrik dari $v_{i}$ di $S$. Lebih lanjut $S$ himpunan dominasi eksentrik terhubung karena $\langle S\rangle$, merupakan subgraf induksi terhubung dari graf sunlet. Akibatnya diperoleh bilangan dominasi eksentrik terhubung $\gamma_{c e}\left(S_{n}\right) \leq n+$ $\left\lceil\frac{n}{3}\right]$. Selanjutnya, akan ditunjukkan bilangan dominasi eksentrik terhubung pada graf sunlet $\gamma_{c e}\left(S_{n}\right)=$ $n+\left\lceil\frac{n}{3}\right\rceil$. Andaikan $\gamma_{c e}\left(S_{n}\right)=n+\left\lceil\frac{n}{3}\right\rceil-1$ maka terdapat $n+\left\lceil\frac{n}{3}\right\rceil-1$ titik sehingga kardinalitas minimum himpunan dominasi eksentrik terhubung pada graf sunlet. Jika terdapat $n+\left\lceil\frac{n}{3}\right\rceil-1$ titik pada himpunan dominasi eksentrik terhubung yang dipilih sebarang maka mengakibatkan minimal 1 titik pada graf sunlet tidak terhubung atau tidak mempunyai titik eksentrik dari $v_{i}$ di $D$ pada graf sunlet. Jadi, dapat disimpulkan bilangan dominasi eksentrik terhubung pada graf sunlet yaitu $\gamma_{c e}\left(S_{n}\right)=n+\left\lceil\frac{n}{3}\right\rceil \mathbf{m}$.

Contoh 7 Diberikan graf sunlet $S_{3}$ dengan 6 titik dan 6 sisi

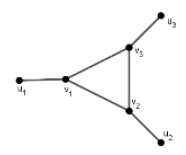

\section{Gambar 3 Graf $S_{3}$}

Pada Gambar 3 dapat dilihat salah satu himpunan dominasi pada graf $S_{3}$ dengan kardinalitas $\underline{\text { minimum yaitu } D=\left\{v_{1}, v_{2}, v_{3}\right\} \text {, sehingga didapat bilangan dominasi } \gamma\left(S_{3}\right)=3 \text {, titik } V-D \text { adalah }}$ 
$\left\{u_{1}, u_{2}, u_{3}\right\}$ saling bertetangga dengan titik dari $D$, didapat titik eksentrik dari graf $S_{3}$ seperti pada Tabel 2.

Tabel 2 Eksentrisitas dari graf $S_{3}$

\begin{tabular}{|c|c|c|}
\hline Titik & Eksentrisitas & Titik eksentrik \\
\hline$v_{1}$ & 2 & $u_{2}, u_{3}$ \\
\hline$v_{2}$ & 2 & $u_{1}, u_{3}$ \\
\hline$v_{3}$ & 2 & $u_{1}, u_{2}$ \\
\hline$u_{1}$ & 3 & $u_{2}, u_{3}$ \\
\hline$u_{2}$ & 3 & $u_{1}, u_{3}$ \\
\hline$u_{3}$ & 3 & $u_{1}, u_{2}$ \\
\hline
\end{tabular}

Pada Tabel 2 diperoleh eksentrisitas dan titik eksentrik pada graf $S_{3}$. Kemudian menentukan himpunan dominasi eksentrik pada graf $S_{3}$ yang diperoleh dari titik $v$ di $V-D$ yang mempunyai setidaknya satu titik eksentrik dari $v$ di $D$. Diketahui bahwa $V=\left\{v_{1}, v_{2}, v_{3}, u_{1}, u_{2}, u_{3}\right\}$, untuk $D^{\prime}=\left\{v_{1}, v_{2}, v_{3}, \mathrm{u}_{1}\right\}$ maka untuk $V-D^{\prime}=\left\{u_{2}, u_{3}\right\}$, karena $D^{\prime}$ merupakan himpunan dominasi eksentrik terhubung dan $\left\langle D>\right.$ juga merupakan subgraf induksi dari graf $S_{3}$ maka di peroleh bilangan dominasi eksentrik terhubung $\gamma_{c e}\left(S_{3}\right)=4$.

\section{Bilangan Dominasi Eksentrik Terhubung pada Graf $B_{2, n}$}

Pada graf bishop dapat dicari bilangan dominasi eksentrik terhubungnya. Berikut ini diberikan proposisi untuk mencari bilangan dominasi eksentrik terhubung pada graf bishop $B_{2, n}$ :

Proposisi 8 Jika diberikan graf $B_{2, n}$ untuk $\geq 2$, dengan $n$ genap

$$
\gamma_{\text {ce }}\left(B_{2, n}\right)=n-1, n \text { genap }
$$

Bukti: Diberikan graf $B_{2, n}$ dengan $V\left(B_{2, n}\right)=\left\{v_{1}, v_{2}, \ldots, v_{n}\right\}$ dan $\left(B_{2, n}\right)=\left\{v_{1} v_{2}, v_{2} v_{3}, \ldots, v_{n-1} v_{n}\right\}$. Misalkan $B_{2, n}$ adalah sebuah lintasan dengan $n$ titik, kemudian terdapat 2 titik yang saling terhubung disebut $u, v$ dalam $B_{2, n}$. Jelas bahwa $D=V\left(B_{2, n}\right)-(u, v)$ adalah himpunan dominasi terhubung terkecil. Misalkan titik eksentrik dari $u \in V\left(B_{2, n}\right)-D$ adalah $v \in V\left(B_{2, n}\right)-D$ dan titik eksentrik dari $v \in V\left(B_{2, n}\right)-D$ adalah $u \in V\left(B_{2, n}\right)-D$. Oleh karena itu, untuk membentuk himpunan dominasi eksentrik maka harus menambahkan titik $u$ atau $v$ yang lain dalam $D$. Ambil sebarang $D=V\left(B_{2, n}\right)-\{v\}$, maka $D$ adalah himpunan dominasi eksentrik terhubung dengan kardinalitas minimum dan $|D|=n-1$. Sehingga $\gamma_{\text {ce }}\left(B_{2, n}\right)=n-1 \mathbf{m}$.

Contoh 9 Diberikan graf bishop $B_{2,4}$ dengan 4 titik dan 3 sisi

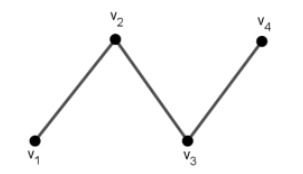

\section{Gambar 4 Graf $\boldsymbol{B}_{\mathbf{2}, \mathbf{4}}$}

Pada Gambar 4 dapat dilihat salah satu himpunan dominasi pada graf $B_{2,4}$ dengan kardinalitas minimum yaitu $D=\left\{v_{1}, v_{3}\right\}$, sehingga didapat bilangan dominasi $\gamma\left(B_{2,4}\right)=4$, titik $V-D$ adalah $\left\{v_{2}, v_{4}\right\}$ saling bertetangga dengan titik dari $D$, didapat titik eksentrik dari graf $B_{2,4}$ seperti pada Tabel 3 . 
Tabel 3 Eksentrisitas dari graf $B_{2,4}$

\begin{tabular}{|c|c|c|}
\hline Titik & Eksentrisitas & Titik eksentrik \\
\hline$v_{1}$ & 3 & $v_{4}$ \\
\hline$v_{2}$ & 2 & $v_{4}$ \\
\hline$v_{3}$ & 2 & $v_{1}$ \\
\hline$v_{4}$ & 3 & $v_{1}$ \\
\hline
\end{tabular}

Pada Tabel 3 diperoleh eksentrisitas dan titik eksentrik pada graf $B_{2,4}$. Kemudian ditentukan himpunan dominasi eksentrik pada graf $B_{2,4}$ yang diperoleh dari titik $v$ di $V-D$ yang mempunyai setidaknya satu titik eksentrik dari $v_{i}$ di $D$. Diketahui bahwa $V=\left\{v_{1}, v_{2}, v_{3}, v_{4}\right\}$, untuk $D^{\prime}=$ $\left\{v_{1}, v_{2}, v_{3}\right\}$ maka untuk $V-D^{\prime}=\left\{v_{4}\right\}$, karena $D^{\prime}$ merupakan himpunan dominasi eksentrik terhubung dan $\langle D\rangle$ juga merupakan subgraf induksi dari graf $B_{2,4}$ maka di peroleh bilangan dominasi eksentrik terhubung $\gamma_{c e}\left(B_{2,4}\right)=3$.

\section{Bilangan Dominasi Eksentrik Terhubung pada Graf $B_{2, n}$}

Pada graf bishop dapat dicari bilangan dominasi eksentrik terhubungnya. Berikut ini diberikan proposisi untuk mencari bilangan dominasi eksentrik terhubung pada graf bishop $B_{3, n}$ :

Proposisi 10 Jika diberikan graf $B_{3, n}$ untuk $n \geq 2$, dengan $n$ genap maka

$\gamma_{c e}\left(B_{3, n}\right)=\left\{\begin{array}{cc}2, & n=2 \\ n-1, & 4 \leq n \leq 8 \\ n-2, & 10 \leq n \leq 18\end{array}\right.$

Bukti:Diberikan graf bishop $B_{3, n}$ untuk $n \geq 2$ graf bishop terbentuk dari pergerakan bishop pada permainan catur, dengan himpunan titik $V\left(B_{3, n}\right)=\left\{v_{1}, v_{2}, \ldots, v_{\frac{3 n}{2}}\right\}$.

Kasus I: jika $n=2$

Misalkan ambil sebarang $v_{i} \in V\left(B_{3, n}\right)$, dengan $i=1,2, \ldots, n$. Sehingga titik $v_{i}$ akan mendominasi maksimal 2 titik lainnya ( 3 dengan dirinya sendiri ). Oleh karena itu dapat dipilih salah satu himpunan dominasi eksentrik terhubung pada graf bishop $\left(B_{m, n}\right)$ yaitu $\left\{v_{2}, v_{3}\right\}$ untuk $n=2 k, k=1$ sehingga diperoleh bilangan dominasi eksentrik terhubung $\gamma_{c e}\left(B_{3, n}\right)=2$. Selanjutnya akan ditunjukkan bilangan dominasi eksentrik terhubung pada graf bishop $\gamma_{c e}\left(B_{3, n}\right)=2$. Andaikan $\gamma_{c e}\left(B_{3, n}\right)=$ $(2-1)$ maka terdapat $(2-1)$ titik sehingga kardinalitas minimun himpunan dominasi eksentrik terhubung pada graf bishop. Jika terdapat $(2-1)$ titik pada himpunan dominasi eksentrik terhubung yang dipilih sebarang maka mengakibatkan minimal 1 titik pada graf bishop tidak mempunyai titik eksentrik dari $v_{i}$ di $D$ pada graf bishop. Jadi, dapat disimpulkan bilangan dominasi eksentrik terhubung pada graf bishop yaitu $\gamma_{c e}\left(B_{3, n}\right)=2 \mathbf{m}$.

Kasus II: jika $4 \leq n \leq 8$

Misalkan ambil sebarang $v_{i} \in V\left(B_{3, n}\right)$, dengan $i=1,2,3, \ldots, n$. Sehingga titik $v_{i}$ akan mendominasi maksimal 4 titik lainnya ( 5 dengan dirinya sendiri ). Oleh karena itu dapat dipilih salah satu himpunan dominasi eksentrik terhubung pada graf bishop $\left(B_{m, n}\right)$ yaitu

$S=\left\{v_{2}, v_{3}, v_{5}, \ldots, v_{\frac{3 n}{2}-3}, v_{\frac{3 n}{2}-1}\right\}$ untuk $n=2 k+2, k=1,2$

$S=\left\{v_{2}, v_{3}, v_{5}, v_{7}, v_{9}, \ldots, v_{\frac{3 n}{2}-2}, \frac{v_{3 n}}{2}\right\}$ untuk $n=2 k+2, k=3$.

Dari sini $S$ himpunan dominasi eksentrik karena terdapat minimal satu titik eksentrik dari $v_{i}$ di S. Lebih lanjut $S$ himpunan dominasi eksentrik terhubung karena $\langle S\rangle$ merupakan subgraf induksi terhubung dari graf bishop. Akibatnya diperoleh bilangan dominasi eksentrik terhubung $\gamma_{c e}\left(B_{3, n}\right) \leq$ $n-1$. Selanjutnya akan ditunjukkan bilangan dominasi eksentrik terhubung pada graf bishop 
$\gamma_{c e}\left(B_{3, n}\right)=n-1$. Andaikan $\gamma_{c e}\left(B_{3, n}\right)=(n-2)$ maka terdapat $(n-2)$ titik sehingga kardinalitas minimum himpunan dominasi eksentrik terhubung pada graf bishop. Jika terdapat $(n-2)$ titik pada himpunan dominasi eksentrik terhubung yang dipilih sebarang maka mengakibatkan minimal 1 titik pada graf bishop tidak terhubung atau tidak mempunyai titik eksentrik dari $v_{i}$ di $D$ pada graf bishop. Jadi, dapat disimpulkan bilangan dominasi eksentrik terhubung pada graf bishop yaitu $\gamma_{c e}\left(B_{3, n}\right)=$ $n-1 \mathbf{m}$.

Kasus III: jika $10 \leq n \leq 18$

Misalkan ambil sebarang $v_{i} \in V\left(B_{3, n}\right)$, dengan $i=1,2,3, \ldots, n$. Sehingga titik $v_{i}$ akan mendominasi maksimal 4 titik lainnya ( 5 dengan dirinya sendiri ). Oleh karena itu dapat dipilih salah satu himpunan dominasi eksentrik terhubung pada graf bishop $\left(B_{3, n}\right)$ yaitu

$S=\left\{v_{3}, v_{5}, v_{7}, v_{10}, v_{13}, \ldots, v_{\frac{3 n}{2}-1}, \frac{v_{3 n}}{2}\right\}$ untuk $n=4 k+2, k=2,3,4$

$S=\left\{v_{3}, v_{5}, v_{7}, v_{10}, v_{13}, \ldots, v_{\frac{3 n}{2}-2}, v_{\frac{3 n}{2}}\right\}$ untuk $n=4 k, k=3,4$.

Dari sini $S$ himpunan dominasi eksentrik karena terdapat minimal satu titik eksentrik dari $v_{i}$ di $S$. Lebih lanjut $S$ himpunan dominasi eksentrik terhubung karena $\langle S\rangle$ merupakan subgraf induksi terhubung dari graf bishop. Akibatnya diperoleh bilangan dominasi eksentrik terhubung $\gamma_{c e}\left(B_{3, n}\right) \leq$ $n-2$. Selanjutnya akan ditunjukkan bilangan dominasi eksentrik terhubung pada graf bishop $\gamma_{c e}\left(B_{3, n}\right)=n-2$. Andaikan $\gamma_{c e}\left(B_{3, n}\right)=(n-2)-1$ maka terdapat $(n-2)-1$ titik sehingga kardinalitas minimum himpunan dominasi eksentrik terhubung pada graf bishop. Jika terdapat $(n-2)-1$ titik pada himpunan dominasi eksentrik terhubung yang dipilih sebarang maka mengakibatkan minimal 1 titik pada graf bishop tidak terhubung atau tidak mempunyai titik eksentrik dari $v_{i}$ di $D$ pada graf bishop. Jadi, dapat disimpulkan bilangan dominasi eksentrik terhubung pada graf bishop yaitu $\gamma_{c e}\left(B_{3, n}\right)=n-2 \mathbf{m}$.

Contoh 11 Diberikan graf bishop $B_{3,4}$ dengan 6 titik dan 8 sisi

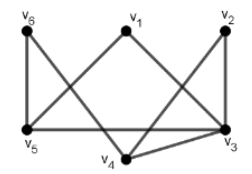

Gambar 5 Graf $B_{3,4}$

Pada Gambar 5 dapat dilihat salah satu himpunan dominasi pada graf $B_{3,4}$ dengan kardinalitas minimum yaitu $D=\left\{v_{3}, v_{4}\right\}$, sehingga didapat bilangan dominasi $\gamma\left(B_{3,4}\right)=2$, Himpunan $V-D$ adalah $\left\{v_{1}, v_{2}, v_{5}, v_{6}\right\}$ saling bertetangga dengan titik dari $D$, didapat titik eksentrik dari graf $B_{3,4}$ seperti pada Tabel 4.

Tabel 4 Eksentrisitas dari graf $B_{3,4}$

\begin{tabular}{|c|c|c|}
\hline Titik & Eksentrisitas & Titik eksentrik \\
\hline$v_{1}$ & 2 & $v_{2}, v_{4}, v_{6}$ \\
\hline$v_{2}$ & 2 & $v_{1}, v_{5}, v_{6}$ \\
\hline$v_{3}$ & 2 & $v_{6}$ \\
\hline$v_{4}$ & 2 & $v_{1}, v_{5}$ \\
\hline$v_{5}$ & 2 & $v_{2}, v_{4}$ \\
\hline$v_{6}$ & 2 & $v_{1}, v_{2}, v_{3}$ \\
\hline
\end{tabular}

Pada Tabel 4 diperoleh eksentrisitas dan titik eksentrik pada graf $B_{3,4}$. Kemudian ditentukan himpunan dominasi eksentrik pada graf $B_{3,4}$ yang diperoleh dari titik $v$ di $V-D$ yang mempunyai setidaknya satu titik eksentrik dari $v$ di $D$. Diketahui bahwa $V=\left\{v_{1}, v_{2}, v_{3}, v_{4}, v_{5}, v_{6}\right\}$, untuk $D^{\prime}=\left\{v_{2}, v_{3}, v_{4}\right\}$ maka untuk $V-D^{\prime}=\left\{v_{1}, v_{5}, v_{6}\right\}$, karena $D^{\prime}$ merupakan himpunan dominasi eksentrik terhubung dan 
$<D>$ juga merupakan subgraf induksi terhubung dari graf $B_{3,4}$ maka di peroleh bilangan dominasi eksentrik terhubung $\gamma_{c e}\left(B_{3,4}\right)=3$.

\section{KESIMPULAN}

Bilangan dominsi eksentrik terhubung adalah kardinalitas minimum dari himpunan dominasi eksentrik terhubung. Bilangan dominasi eksentrik terhubung pada graf sunlet dan graf bishop, diperoleh dengan cara mencari satu persatu bilangan dominasi eksentrik terhubung dari beberapa graf yang dibahas, sehingga diperoleh pola bilangan dominasi eksentrik terhubung pada masing-masing graf. Berdasarkan proses-proses tersebut, maka dapat disimpulkankan bilangan dominasi eksentrik terhubung pada graf sunlet dan graf bishop yaitu:

1. Bilangan dominasi eksentrik terhubung pada graf sunlet :

$$
\gamma_{\text {ce }}\left(S_{n}\right)= \begin{cases}n+\left[\frac{n}{2}\right], & n \geq 4, \text { untuk } n \text { genap } \\ n+\left[\frac{n}{3}\right], & n \geq 3, \text { untuk } n \text { ganjil }\end{cases}
$$

2. Bilangan dominasi eksentrik terhubung pada graf bishop $B_{2, n}$ dan $B_{3, n}$ dengan $n$ genap :

$$
\begin{gathered}
\gamma_{\text {ce }}\left(B_{2, n}\right)=n-1 \\
\gamma_{c e}\left(B_{3, n}\right)=\left\{\begin{array}{cc}
2, & n=2 \\
n-1, & 4 \leq n \leq 8 \\
n-2, & 10 \leq n \leq 18
\end{array} .\right.
\end{gathered}
$$

DAFTAR PUSTAKA

[1] Santoso B, Djuwandi, Soelistyo RH. Bilangan Dominasi dan Bilangan Kebebasan Graf Bipartit Kubik. Jurnal Matematika. 2012. Vol. 15. No. 1.

[2] Chartrand G, Zhang P. Chromatic Graph theory. Crc press Company. New York. 2009.

[3] Sumarsono T, Soelistyo RH, Sumanto YD. Jurnal Matematika. 2016. No.4.

[4] Munir R. Matematika Diskrit. Informatika Bandung, Bandung. 2010.

[5] Shobana A, Logapriya. Domination Number Of N-Sunlet Graph. International Journal Of Pure and Applied Mathematic. 2018. Vol. 118. No.20: 1149-1152.

[6] Johnson Kalhleen. On Domination Chain Of M By N Chess Graphs. 2018.

[7] Hussain R Jahir, Begam A Fathima. Connected Eccentric Domination In Graphs. International Journal Of Innovative Trends In Engineering. 2015. Vol. 4. No. 1: 42-47.

BAMBANG PONIMAN : Jurusan Matematika FMIPA Untan, Pontianak, bambangponiman94@gmail.com

YUNDARI : Jurusan Matematika FMIPA Untan, Pontianak, yundari@math.untan.ac.id

FRANSISKUS FRAN : Jurusan Matematika FMIPA Untan, Pontianak, fransiskusfran@math.untan.ac.id 